\title{
Ju Er Hutong Project: A Rehabilitation Model or an
}

\section{Unsuccessful Attempt?}

\author{
Giuseppe Cinà and Qi Mu \\ Interuniversity Department of Regional and Urban Studies and Planning (DIST), Polytechnic and University of Turin, Turin 10129, \\ Italy
}

\begin{abstract}
What will be the future of Chinese urban heritage in the context of globalisation and a socialist market? Ju Er Hutong, as one of the first rehabilitation projects to take place during China's late-1980s housing reforms, is generally considered a successful initiative in terms of urban regeneration and historic area conservation. To what extent does this success demonstrate a capacity to develop new policies and a new planning approach in the current Chinese urban regeneration process? To answer this question, and to summarize its achievements and its remaining unsolved problems, this paper provides the following insights: (1) an analysis of the evolution of Ju Er Hutong to its current form; (2) a literature review concerning the background and the outcome of the rehabilitation process; and (3) a critical assessment of the overall process, so as to summarize its constitutive advantages and problems.
\end{abstract}

Key words: Urban heritage, old city preservation, Ju Er Hutong, urban restructuring, conservation.

\section{Introduction}

Widely documented Hutong is an important carrier of the urban culture of Beijing, and is the basic unit of spatial structure within the ancient city, through which the principles of its organization take shape. In order to offer a description of the $\mathrm{Ju}$ Er Hutong (Chrysanthemum Lane) preservation policies and to provide a critical assessment of their implementation, it is worth examining its historical and morphological evolution.

In order to better understand the original formation of Ju Er Hutong and its correspondence to the symbolic hierarchy of housing patterns in ancient Beijing, a set of important spatial characters and spatial evolutions will be presented.

The formation of the Chinese urban morphology, with its rigid symmetry and formalized symbolism, was based on the guidelines in Rites of Zhou, a fundamental work on State bureaucracy and organizational theory. Its chapter Kao Gong Ji, a set of

Corresponding author: Giuseppe Cinà, M.Sc. architecture, Ph.D. urban planning, Associate professor. Research fields: urban heritage preservation, urban project, and peri-urban agriculture. assignments and guidelines compiled by realm officials, acted as an official technical regulation. The basic architectural housing typology in China was the courtyard house, whose dimensions were all predefined by urban schemes. The most common housing unit corresponding to an administrative unit within the residential spatial organization of Beijing, generally called Li Fang, was shaped before the 9th century. At the end of Song dynasty (960-1279), there were 62 Li Fang in Beijing. Each Li Fang corresponds to a rectangle of land of about $0.2 \mathrm{~km}^{2}$ [1]. The word "Fang" means "square", which indicates the original geometric units. Walls enclose every Li Fang and the gates were closed and guarded every night. Outside the walls, the main roads are symmetrically aligned, while residential buildings were built along the small internal alleys and form the sub-zones [2]. With the development of commercial activities, the frontier between the commercial and residential areas was removed, but the function of Li Fang was redefined in an administrative unity, now called "Fang Xiang" (meaning "block and lane"), abbreviated as Fang and maintaining the same surface area. Ju Er Hutong 
belonged to the Fang called Zhao Hui. In every Fang, there were also small markets and schools that constituted a new settlement system, serving basic economic and social functions.

Beijing became significant when it was rebuilt in 1260 by Kublai Khan as the capital city of the Yuan dynasty. The reconstruction was based on the guidelines of Kao Gong Ji and followed the spatial structure of the previous capital cities [3]. The scale of every category of streets and the technical width between two Hutong (44 steps, about 67.76 meters) was predefined in the Kao Gong Ji (Fig. 1). According to Deng [2], the surface of the basic unit of the block is about $4,535 \mathrm{~m}^{2}$, meaning that one Hutong could include ten normal courtyard units. This conforms to the "square form" of the spatial model mentioned before. By this regulation and the consequent urban texture, the urban morphology of ancient Beijing was perfectly shaped. At the same time, it gave birth to the urban form of Ju Er Hutong which has played a core role in the historical area of Beijing until today.

During the Qing dynasty (1644-1912), the policy of separation of military and residential functions influenced the formation of Ju Er Hutong. In general, Manchu and Mongolian military communities, as the most efficient military organizations and having high social and political positions, were all settled in the Internal City (Nei Cheng), while the ethnic Han community could only live in the External City. The area of $\mathrm{Ju}$ Er Hutong was located in the northeast part of the Internal City and administrated by the Manchu [4]. Therefore, its population of roughly 2,500 people was comprised entirely of Manchu soldiers and their families. At the end of the Qing dynasty, the Han community were allowed to live in the Internal City and the restriction of settlement to Manchu and Mongolian military communities was lifted [5]. After this, the social composition of local residents and its impact on the spatial organization of the urban fabric became more complicated.

Despite these changes, the urban fabric of today's Ju Er Hutong evolved according to the traditional housing typology of Chinese architecture. Its pattern was based on different sizes of courtyard buildings articulated organically, in order to form an articulated building system [3].

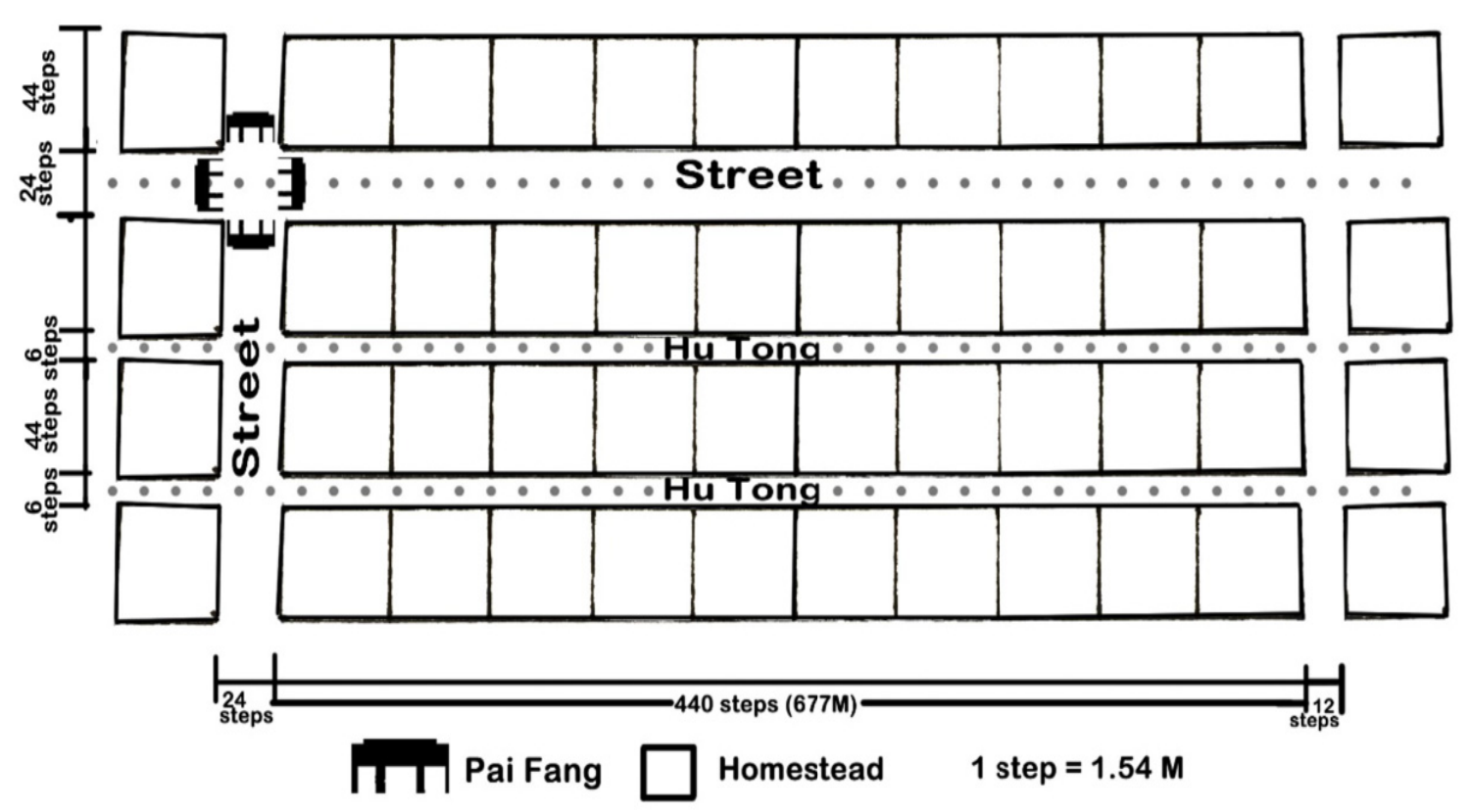

Fig. 1 The basic pattern of the urban block composition of Beijing during the Yuan dynasty, based on the Hutong system. Source: Deng [2]. 


\section{Methodology}

This paper is based on a series of literature review on the Chinese urban morphology and the existing research outcomes related to the morphological transformation of the case study. In order to provide a critical assessment on the overall approach of the rehabilitation project, we carried out field survey in March, 2016 and 2017 to better understand the modifications and social transformations occurred before/after the accomplishment of the project, some recurrent issues concerning physical/societal spheres in today's Ju Er Hu Tong has been emphasized and argued. Particular attention has been paid to the interventions of the built environment.

Last but not the least, we conducted observation in the field, concerning: (1) spatial transformations of indoor and open spaces in Ju Er Hutong; (2) social composition and daily activities of inhabitants; (3) spatial relation between Ju Er Hutong and the surrounding area, paying particular attention to the influence of planning background and subsequent impact on the tourism development and the changes occurred to local inhabitants.

\section{A New Type of Courtyard House as a Model for Old City Rehabilitation}

The Ju Er Hutong rehabilitation project was one of a number of experimental projects aiming to establish new urban renewal solutions in housing settlements with high historical and environmental value, including a specific conservation plan focused on the South Gong and Drum Lane area.

$\mathrm{Ju}$ Er Hutong rehabilitation project (8.2 ha) was designed by $\mathrm{Wu}$ Liangyong, a Chinese urban planner and a professor in urban planning, architecture and design. The project is currently cited as an award-winning case due to its attempts to adopt more conservative (or at least less destructive) measures for the maintenance of the historical fabric [6]. The project used the principle of "organic renewal" which was designed "to keep the part still in good shape, repair some of the walls and roofs, and make new construction only when we have to". However, the realization of his idea appears controversial and another interpretation given by Ian [7] is more likely to be appropriate to the situation: "instead of clearing out entire neighborhoods, you saved what could be saved and built similar-sized and similar-looking buildings to replace those that truly were hopeless".

To untangle this controversial matter, it is worth summarising the process of the whole project to establish close insights into its achievements and failures. The project was developed in four distinct phases (Fig. 2).

The first phase was focused on No. 41 Courtyard, a small area of 0.209 ha where the dwellers lived in extremely poor conditions and the residents had a strong desire to improve their living standards. Frequent flooding, lack of sunlight and distant public toilets all contributed to a poor quality of life. Moreover, in order to create additional space for expanding families, the public space in the courtyard was illegally occupied, resulting in $84 \%$ of the plot being covered by buildings, as opposed to the planned proportion of $58 \%$. After a series of studies on the spatial characteristics of traditional courtyards, the design team decided to utilize the so called "standard courtyard buildings", reorganizing the spatial structure by adding two levels to both the south and north sides and one level to the west and east sides to increase the per capita living space. Furthermore, considering the needs of residents, the design team conceived several types of layout equipped with kitchen and bathroom, and also some outdoor spaces such as balconies and roof terraces. During this phase seven old courtyard houses were demolished, and 46 apartments were newly constructed, which resolved the basic living problems for 44 families (the other two apartments were sold at the market price).

The preparation for the second phase, including an 


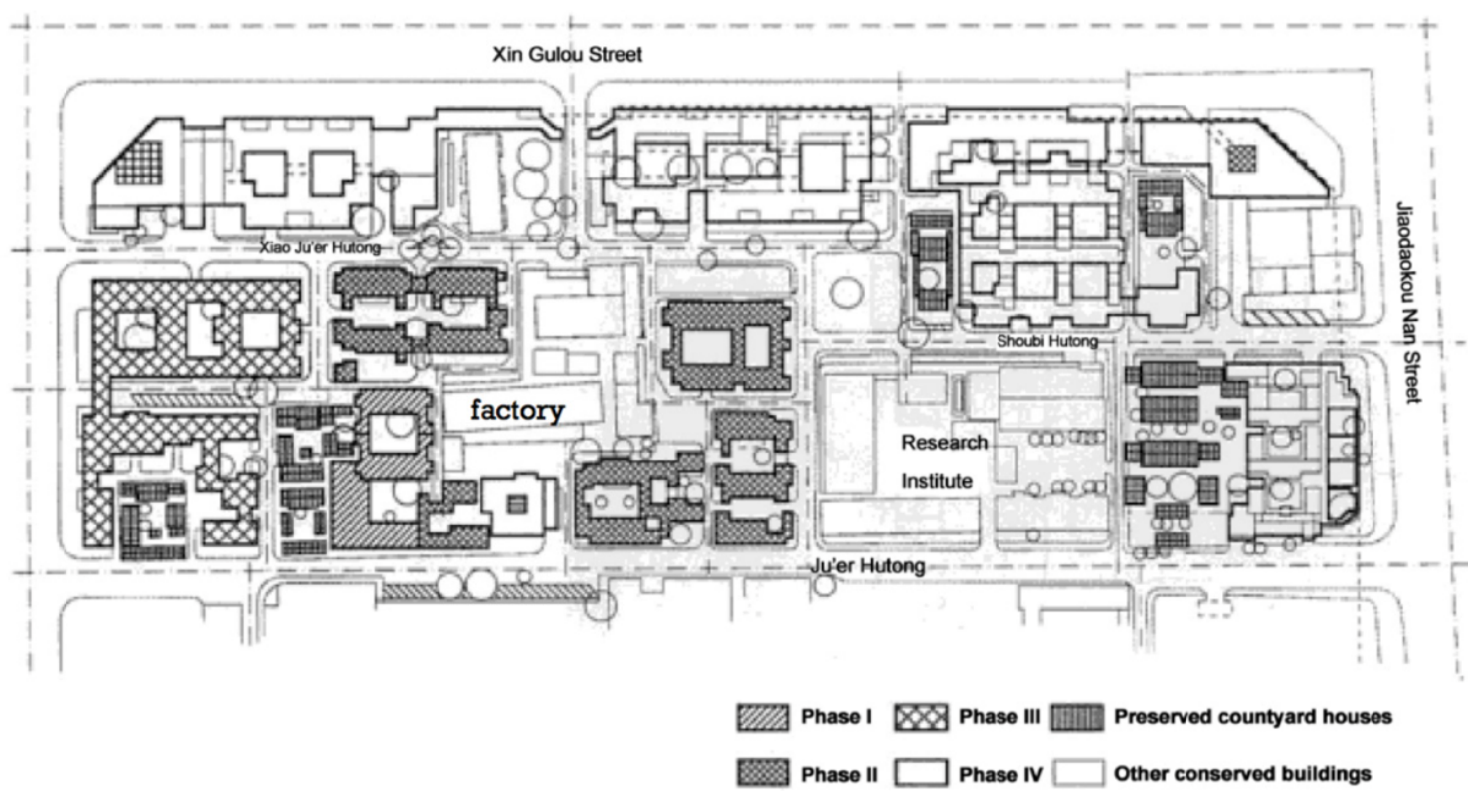

Fig. 2 Master plan for the Ju Er Hutong rehabilitation project. Source: $\mathrm{Wu}[8]$.

area of 1.14 ha, started immediately after the completion of the drawing preparation of the first phase. The main area of the second phase actually encircled a factory, which was obviously difficult to relocate because of its spatial character. For this reason, only one storey of the factory was included as part of the second phase of the rehabilitation project. In this second phase, instead of the rectangular form of the new courtyard building of the No. 41 Courtyard, a more various form of courtyard plan was applied in order to meet the requirements of 192 dwellers as well as to save the ancient trees and to leave space for the circulation system. In addition, the issue of community's social construction was taken into account, consequently a community center of $300 \mathrm{~m}^{2}$ was also completed.

The third phase involved an area of 0.88 ha, composed of various other building types. First, for the residential section, seventy-one apartments were built, creating $6,116 \mathrm{~m}^{2}$ of residential floor area of $86.1 \mathrm{~m}^{2}$ per household. The courtyard buildings were designed with greater open space and more "narrow form" units. Secondly, the project started to focus on developing mixed commercial-residential buildings alongside public service spaces. For instance, the floor area of a hotel of 1,704.3 $\mathrm{m}^{2}$ was doubled [8].

The final phase included an area of 6.58 ha and adopted the same design approach. It should be stressed that in this phase most of the residential areas were transformed into commercial ones. For instance, a residential nucleus of $19,300 \mathrm{~m}^{2}$ was converted to commercial space, and consequently 1,200 residents were obliged to move out. Furthermore, 930 families were living in this area, a number which decreased to 500 after the project. Most importantly, in order to create a "multifunctional courtyard compound system", commercial real estate was included in the north of the area, directly facing the main street of South Gong and Drum Lane, with the aim of increasing the income of the whole project [3].

Although the rehabilitation project aimed to preserve the morphology of the traditional pattern and style of South Gong and Drum Lane area, it also included changes and demolitions according to assessments of building quality status carried out by the design team. The buildings present in the area were divided into three categories:

(1) High quality and recently constructed buildings 
(such as the two factories erected in the 1970s), constituted $16.2 \%$ of the whole area;

(2) Courtyard buildings in fair condition, needing to be renewed and reused, accounted for $6.5 \%$;

(3) Buildings in poor condition, to be demolished, comprised $77.3 \%$ of the whole area of 8.2 ha.

In summary, the main changes from the original courtyard buildings to the new ones are as below:

- From a set of volumes with only the ground level to vertical multi-storey buildings;

- From a traditional morphology to a new and more regular one;

- From residential use to a more commercial-touristic use;

- From a low-income community to a gentrified community;

- From a low housing value area to a high housing value area. The low-income inhabitants were mainly displaced elsewhere, changing the social composition of the residents and resulting in a decrease of identity.

\subsection{No. 41 Courtyard, a Pioneer Experiment in the Old Urban Fabric Renewal}

The new building fabric was based on a new standard courtyard type which was developed on a scale of about $1,000 \mathrm{~m}^{2}$ including a yard of about 195 $\mathrm{m}^{2}$. For the sake of improving indoor daylight and to strengthen the live ability of the courtyard, the east and west wings of the buildings were reduced to two levels. Moreover, through adopting a varying range of architectonical elements, a series of external, private and semi-private spaces were created (e.g. balconies, terraces, corridors, etc.). It is worth stressing that this variety of architectonical elements was obtained by increasing the costs of a higher plot ratio and a higher fee of construction. Nevertheless, the plot ratio was not high enough compared to the expected average density of renewal (Table 1). As a result, after the completion of the project in 1994, the authorities decided not to extend this experiment to other urban areas in Beijing [8].
At the end of the project in No. 41 Courtyard, the per capita living space was expanded from $5.2 \mathrm{~m}^{2}$ to $12 \mathrm{~m}^{2}$ and the floor area ratio was increased to 1.32 . Furthermore, the minimum width of the alley was enlarged by adding 2 meters to the north side in order to guarantee an appropriate public space for circulation.

\subsection{Finance}

The total investment in the renovation of No. 41 Courtyard was 2.84 million Yuan (including the resettlement fees, costs of infrastructure, etc.). In order to provide affordable housing units, a housing cooperative was set up. The thirteen original families who wanted to move back to the renewed courtyard paid the cost of the construction, contributing 1.47 million Yuan through cooperative financing. Those original residents who could not pay the price set by public authorities, or were unwilling to move back, had the right to exchange their units with the residents of other areas. At the end of the first phase of the project, leaving aside the houses rebought by original residents, the other ten houses were sold at a market price totalling 1.4 million Yuan, for the purpose of recovering the construction cost. The total recovery of funds was 2.87 million Yuan, which was sufficient to balance the budget [8].

\subsection{Inhabitants and Identity Facing a Commercial and Market-led Development}

The original buildings in No. 41 Courtyard included a Ming dynasty-era temple named Hongdeshanlin, administrated by a temple nearby called Yuan'en, which was ruined during the Qing dynasty. At the end of the Qing dynasty, the No. 41 Courtyard fell into disrepair. After the invasion by the Japanese army, many people settled in this yard to start their new life in the context of the new socialist society. It's noteworthy that before the foundation of the New China, housing stock had been exclusively in private ownership. However, after the first Five-year plan (1953-1957), the socialist goal of providing a shelter for everyone 


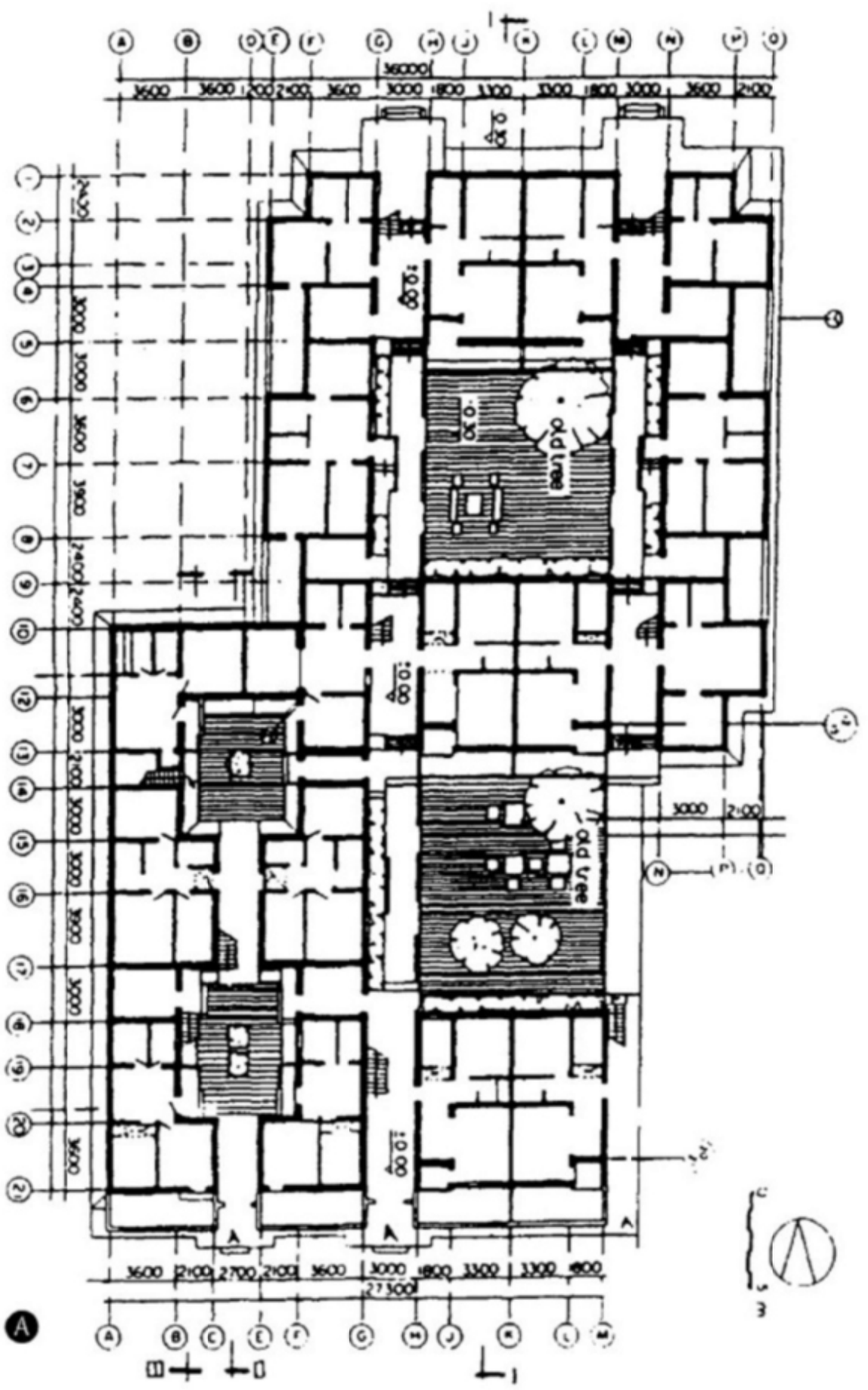

Fig. 3 Plan of the ground floor of No. 41 courtyard.

Source: $\mathrm{Wu}[3]$.

Table 1 Statistics for Ju Er Hutong before and after the rehabilitation of No. 41 courtyard.

\begin{tabular}{llllllll}
\hline & Floor area & Dwellers & $\begin{array}{l}\text { Dwellers per } \\
\text { household }\end{array}$ & Dwellings & $\begin{array}{l}\text { Density } \\
\text { (dwellers/ha) }\end{array}$ & $\begin{array}{l}\text { Floor area per } \\
\text { person }\end{array}$ & $\begin{array}{l}\text { Illegally built area } \\
\text { within the courtyard }\end{array}$ \\
\hline Before & 1,085 & 138 & 3.14 & 41 & 673 & 7.86 & $450 \mathrm{~m}^{2}$ \\
After & 2760 & 133 & 2.98 & 46 & 649 & 20.75 & $0 \mathrm{~m}^{2}$ \\
\hline
\end{tabular}

Source: $\mathrm{Wu}[3]$. 
transformed house ownership profoundly, as private housing was transferred to the ownership of the local authorities. As the result, many working-class families coming from rural areas moved into courtyard houses [9], so that "multifamily courtyards" gradually formed, which were called "Da Za Yuan", (meaning "big messy yard"). Inevitably, in order to increase living space, residents transformed various rooms of the Hongdeshanlin Temple into residential ones. In the 1980s, there were 24 families ( 85 people in total) living in No. 41 Courtyard simultaneously [8]. Alongside the issue of the increase in inhabitants discussed above, at the end of the 80s, the majority of residents in No. 41 Courtyard were young people. Although the population was limited by the one child policy, a further increase in residents could be expected reasonably. In fact, as we can see today, the current spatial structure is not able to meet the increasing demand of dwellers.

The rehabilitation project altered the composition of residents at the beginning of the 90s. The thirty-one families who decided to not purchase a dwelling in the new courtyard, or could not buy the units where they lived before, were given three choices as follows:

(1) To resettle to other government-owned housing located in the old city, generally in bad condition;

(2) To move to new residences located outside of the old city and provided by the government at a low price as one of the benefit conditions;

(3) To exchange their purchase right at the preferential rate for a house elsewhere [8].

According to the survey on the status of resettlement of original and new inhabitants, thirteen original families returned to the new courtyard together with thirty-one new families, and half of them reported feeling at home after having lived in the new type of courtyard for one year [10]. Meanwhile, four families were relocated to new residences situated in suburban areas, twenty-one families moved to other residences inside the old city, and six families used their "right of exchange" and purchased a house elsewhere.

Most residents apparently did not want to leave the old city because it offered more convenient transportation and educational conditions. However, by simply providing higher-quality housing at a lower price, the public authority and the design team received positive feedback from those families who moved out. In 1990, 26 of 31 families participated in the post-project survey of No. 41 Courtyard, and as $\mathrm{Wu}$ [8] states: "none of those surveyed expressed the regret over the choice they had made".

Today, householders who are still living in poor quality courtyard buildings expect renewal of their homes as in the 1989 project. The current housing price in the renewed area is above 100,000 Yuan (about 13,600 euro $\left./ \mathrm{m}^{2}\right)^{1}$ and is still growing, so Ju Er Hutong can be counted as part of the Beijing "urban renaissance" process, as well as under threat of gentrification [11].

\section{The Transformation of Public and Private Spaces}

In ancient China, public spaces were usually huge in scale for gatherings of political servants, and their use for free association was prohibited in order to prevent popular revolt [12]. Open spaces for public civic activities were rare because the city was clearly divided into residential and commercial functions. But today, public spaces are a fundamental aspect of cities' live ability, as they encourage everyday activities, and increase social interaction [13]. Therefore, it is worth recalling the specificities of the public spaces in ancient Hutong:

- Thousands of years of feudal society had fettered the formation of an autonomous public space, so their locations were mainly related to indispensable daily activities based in a linear common space, called a Hutong, a lane acting as an extension of residents' living space.

- The small scale of their open space made them

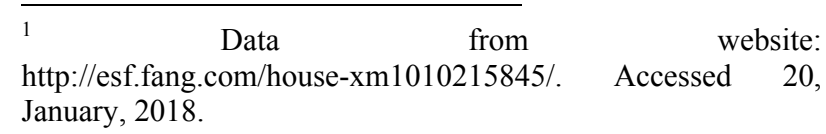




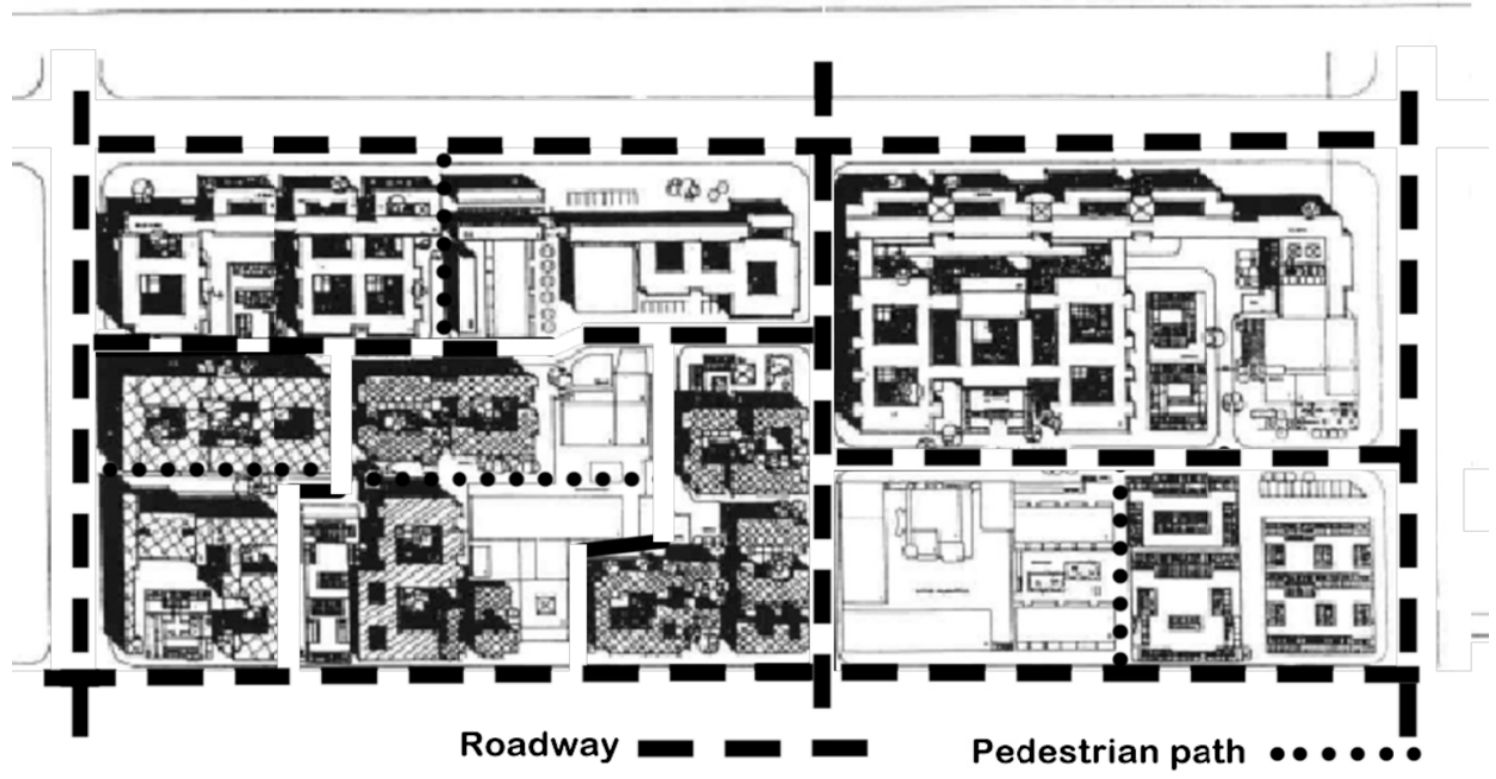

Fig. 4 Approach system of Ju Er Hutong.

Source: Sun [10].

easily reachable and perceivable. Therefore, they were also suitable for pedestrian mobility and small business activities.

Thanks to the rehabilitation project and many other conservative schemes ${ }^{2}$, the residential function of Ju Er Hutong maintains its relevance, but we do see that the whole area has transitioned to a double functional value: residential and commercial-tourism. Therefore, it can be considered an intermediate solution between traditional residential area and commercial area.

\subsection{Public Paths among Courtyard Compounds}

In view of the belief that "Hutong are the blood capillaries of Beijing Old City", the rehabilitation

\footnotetext{
${ }^{2}$ In 1999, Beijing municipal government issued the Planning on the Protection and Control Scope of the History and Culture Protection Area of the Old City of Beijing (April 1999) as a general initiative action in order to establish more detailed plans. Furthermore, the Beijing Municipal City Planning Commission worked with many universities and institutes to produce the Conservation Plan for the 25 Historic Areas in Beijing Old City (Beijing Municipal City Planning Commission, 2002). The South Gong and Drum Lane area and Ju Er Hutong were included. The Conservation Plan evidenced the goal "to preserve the overall style and features of the historical areas" and "to improve environmental quality and infrastructure as well as residents' living standard...".
}

project attempted to maintain this urban character. The design group took the networks of the courtyard compounds in Suzhou as a reference, inserting long paths of about $50 \mathrm{~m}$ among the courtyards, so as to draw influence from traditional urban morphology and recall the ancient Chinese space of daily interaction (Fig. 4). Yet today, due to the socioeconomic development of the area and the increased demand for leisure and sportive activities, the paths and other open spaces have not achieved an appropriate scale; as a result, the current public spaces do not match the modern lifestyle of the residents. As we can notice, the outdoor activities of residents in Ju Er Hutong take place directly in the alley, which is mainly used for circulation of cars. Besides this, the only green spaces are a few trees conserved in courtyards.

\subsection{Public Services}

Public services, including social infrastructures such as education, medical care, sports, etc., are an important indicator of the quality of life of residents [14]. In Ju Er Hutong, the only focal point for the gathering of people is the Community Center, a new traditional-style building constructed during the second 
phase of the project which includes an administrative office for the community, a youth activity center, a senior activity center and a community health center. In the Center, a variety of youth activities (e.g., lecture courses, photo exhibitions, and education on law) have been held from the early 90s until today. Besides the public services mentioned above, Ju Er Hutong has few appropriate spaces for sitting and walking due to its "street" spatial character.

It should be also added that congested and chaotic parking is another issue in today's Ju Er Hutong. In Ju Er Hutong, the urban road area ratio is about $15.7 \%$ which has effectively reduced the traffic on the main road [10]. But on the other hand, it produces hazardous circumstances. Although the multi-scale approach system of Ju Er Hutong offers a convenient mode of mobility, the parking issue needs to be resolved for the purpose of improving the safety and urban landscape of the area. In fact, some laws and regulations have introduced possible measures and solutions to resolve the traffic problem. For instance, Measures for the Protection of the Historical and Cultural Landmark of Beijing (Effective) declared "by utilizing various measures or instruments, to activate practical actions to manage, control and limit the excessive use of private cars in the Old City". However, it seems that Ju Er Hutong and the entire South Gong and Drum Lane area are not implementing these regulations.

\subsection{Transformation of Private Residential Spaces from Past to Present}

With the earth-shaking transformation of Chinese society over the last hundred years, Ju Er Hutong has witnessed great changes as well. If we consider the transformations occurred in the context of strictly residential spaces, a variety of significant findings emerge.

The culture of Chinese architecture is fundamentally a culture of courtyard buildings. Whether in palaces or in ordinary houses, courtyards have always been a matrix unit of urban form [15]. The yard also represents the ancient Chinese attitude to the environment, which is reflected by Chinese Feng Shui philosophy. The yard was used for outdoor activities and as shelter from the wind. Besides all these practical functions, the enclosed space offered residents a sense of belonging, improving social cohesion. Enclosed space not only helps to gather individuals and families into a social unit but also permitted the Chinese people to maintain the traditional family model in a relatively stable state.

The yard is also a way to "integrate nature and humanity", which is the core of Taoism. The scale and the volume of building and yard and their close correlation with natural conditions, psychology, and architecture can even reveal surprising results through scientific methods [16, 17]. In Taoism, it is emphasized that "harmony with circumstances" is one of the main criteria when choosing a favorable site for construction, so as to respect nature. The "cosmic breath", wind or energy could be interpreted as "microwave radiation from the sun" [9] that nourishes all things and gathers positive energy for the family. The spatial configuration of the courtyard buildings is considered effective in gathering such energy and refining the circulation of the microclimate. Moreover, the well-organized spatial structure and the garden in the center of the yard provide physical and psychological comfort for inhabitants.

The Ju Er Hutong rehabilitation project started with an intention to keep the matrix of the old courtyard and each compound is organized as two or three single-courtyard buildings, each containing a yard of about $100 \mathrm{~m}^{2}$. Balconies and terraces were designed to create passages and spaces for communication. Besides the improvements in living conditions mentioned above, the volume, the scale, and the facades of the new courtyards have been totally changed. The new type of courtyard was designed to recapture the emotional experiences and intuitive feelings that the spatial character of the traditional courtyard had brought to people once, in order to enhance the affinity of the neighbourhood. 
Table 2 Four examples of recovery between preservation and rehabilitation.

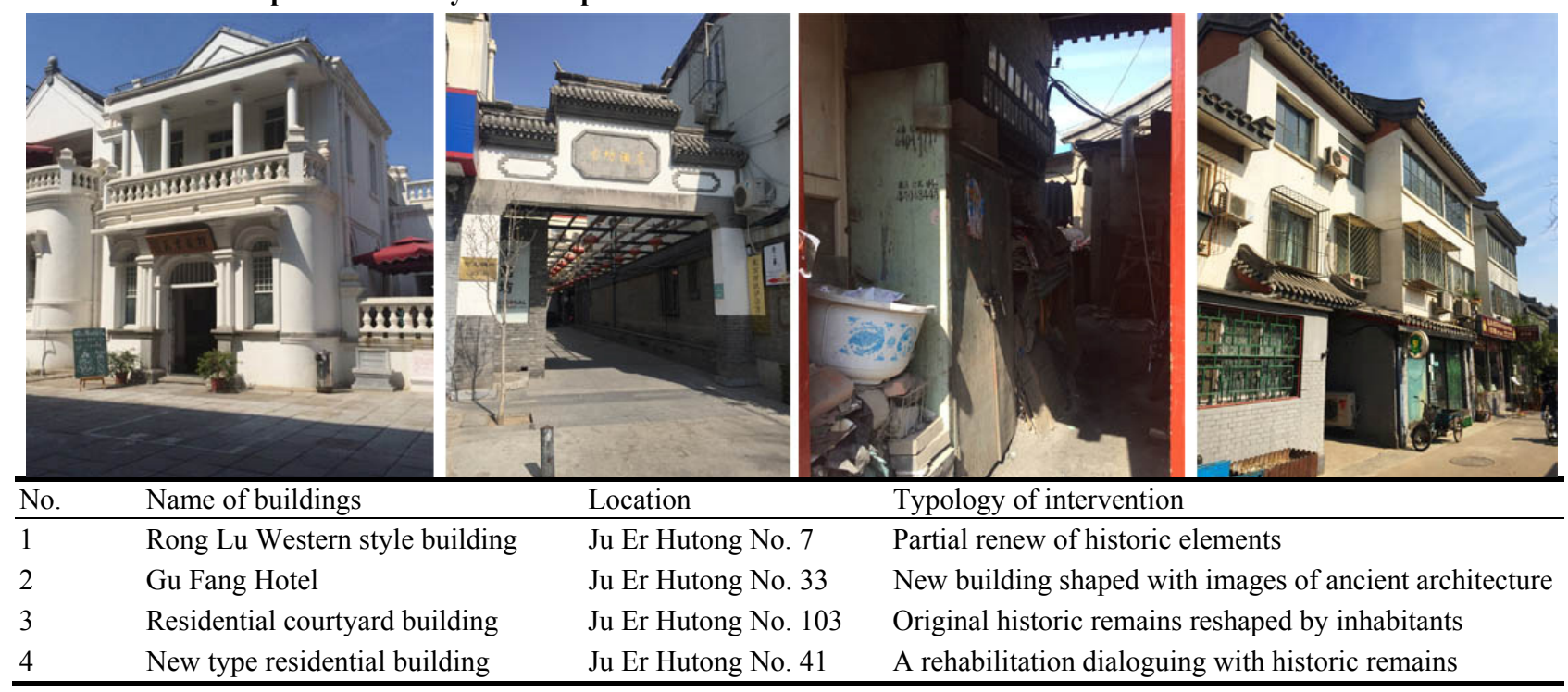

Source: Elaborated by authors.

Today, about $40 \%$ of residents are elderly people and children, whose main activities are household chores, gymnastics and conversation. The yard functions as a semi-private space shared by different families, where daily interactions take place. Nevertheless, based on the survey on feelings of belonging, in Ju Er Hutong, only $20 \%$ of residents think that the new type of courtyard provides the same ambience as the traditional one [10]. Moreover, due to mismanagement by the community, most balconies and terraces are being used as deposit areas, and the corridors are full of rejected materials, which increase the risk of fire.

\section{Four Typologies of Recovery, between Preservation and Rehabilitation Project}

Closely examining the solutions offered by the rehabilitation project in Ju Er Hutong, it is possible to identify various different modes of interventions based on different conservative approaches (see Table 2).

The first mode is the partial renewal of residual elements. Some of the real historic remains can be only traced by identifying the existing architectonical elements and the steles in front of the buildings. The
Rong $\mathrm{Lu}^{3}$ Western style building is one example of this. Rong Lu mansion covered half of the alley, being divided into three sections from west to east, with a western-style building in the west. Unfortunately, although in 2009 it was listed by the district level cultural relics protection unit, only the basic structure, the façade and the external Western style architectural elements have been conserved; the interior has been reconstructed and transformed into a luxury restaurant. In fact, it is a struggle to identify and apply the correct modes of preservation, as the eruption of tourism and rapid economic development strongly influence the practices of conservation of historic centers in China [18].

The second mode consists of the "reinvention" of ancient architecture. One example is located in the $\mathrm{Gu}$ Fang hotel, No. 33 Courtyard. This building represents the majority of recently built pseudo-traditional style buildings whose primary function is commercial. It is artificial although it serves the purpose of attuning the building with the surrounding urban landscape.

\footnotetext{
${ }^{3}$ Rong Lu, (6 April 1836-11 April 1903), was a Manchu statesman and general in the late Qing dynasty.
} 
The third mode refers to buildings completely or partially reshaped by inhabitants for their basic living purposes (e.g., No. 18 Courtyard). This type of intervention is mainly based on maintenance works, and distributed on the south side the lane, where an appropriate conservative measure still needs to be applied to the courtyards (or the still existing "multifamily" courtyards near to No. 18 Courtyard, where it is hard to trace constructive information for individual rooms). Most inhabitants are living here for a short period while in transit during resettlement from other historical areas undergoing renewal projects, and so demonstrated little interest in being visited and interviewed.

The fourth group includes the Ju Er Hutong new courtyards. It is an experimental prototype that, thanks to its redesign and reorganization of traditional courtyard buildings, was considered a new page in the book of Chinese urban heritage rehabilitation by many scholars and commentators. The urban restructuring aimed to preserve some elements of traditional architecture, not by restoring their physical assets but by recalling their social and functional aspects.

Besides the various interventions implemented by different stakeholders for different purposes, there are other buildings of high historical value that are facing embarrassing situations. The two-row courtyard of Rong Lu Ancestral Hall (in Ju Er Hutong No. 3) is one of them. A few old houses were conserved as a part of Rong Lu Ancestral Hall, which was listed by Dongcheng District Cultural Relics Protection Unit in 1986. Thanks to this nomination, the Rong $\mathrm{Lu}$ Ancestral Hall was excluded from the demolition at the end of the $80 \mathrm{~s}$. The building, despite its high historical-cultural value, is suffering from ineluctable dilapidation today. And yet, Rong Lu Ancestral Hall is not a lone case of unsuccessful implementation of conservation regulations. No. 107 Courtyard is a site protected at the district level, and was presumably property of a Qing-dynasty court official (the stone piers indicate the political position of the household).
Despite this, although the integrity of its main door, its building ornaments, and the roofs still demonstrate high historical and artistic value, the courtyard isgravely degraded. In view of the difficulty of finding its original owner, it remains unclear where responsibility for its preservation should lie.

\subsection{A Spontaneous Commercialization Process}

$\mathrm{Ju}$ Er Hutong rehabilitation project produced both an improved residential fabric and a set of related activities. As a consequence, today in the area more than twenty new commercial activities have developed, which are profoundly changing the character of the area. The symbolic design strategies were born to meet the growing nationalism of a powerful country, meantime, "satisfying the emerging commercial elites in a society of growing capitalism" [19]. This Hutong weaves together a number of street frontages, providing the potential for development of commercial spaces. During this process of transformation, the mixed functions make the urban spaces more attractive and liveable. Original residents, foreigners, artists and shops share the space of the Hutong, creating a new cultural environment. On the other hand, an excessive presence of non-residential use leads to a state of social imbalance. As a result of the emergence of commercial spaces, restaurants and bars and other public facilities, the façades as well as the interiors of the houses are filled with modern and foreign elements (e.g., No. 20 Courtyard). In No. 41 Courtyard, the ground floor facing the alley was entirely rebuilt to house a restaurant and a cafè.

In summary, this rehabilitation intervention has involved the reconstruction of a residential system. It has produced an economic revival in the neighborhood which resulted in the launch of a set of tertiary businesses. These activities have been established along the street frontages by replacing previously residential buildings with new buildings.

The public space of the Hutong, previously a lane closed by walls on two sides and occupied by outdoor 
trade activities, has become a "street" with open commercial frontages, often expanded into the inner courtyard. This transformation has produced a total alteration of public space as well as an explosion of retail space, and has also modified the formal articulation of residential spaces.

\subsection{Spontaneous Interventions, and Small-scale} Renewal according to the Demands of Residents

In the courtyard building area of Old City in Beijing, self-maintenance interventions are the most widespread. Interventions implemented by residents are always carried out on a small scale. According to the data provided by Beijing Cultural Heritage Protection Center, $69 \%$ of Old City courtyards were renewed or restructured through spontaneous interventions from 1998 to 2008. It appears that the self-maintenance mode is a good practice because it partially reduces the financial pressure on public authorities, and permits residents to participate more actively in projects. But in many self-maintenance cases, the renewal is hampered by the low economic capacity of the inhabitant. Despite this, compared with large-scale government-led renewal projects, self-maintenance renewal led by residents has the following advantages: (1) the interventions have clear and simple objectives like kitchen-improvement and pavement resurfacing, and it can be accomplished according to personal preference; (2) the self-maintenance process is much more flexible than government-led operations. In an urban renewal project, the government would firstly conduct a survey of the area, then formulate a unified and multi-level protection policy, and finally allocate funds to renovate the area. As such, the needs of each house with different physical conditions and every resident with different demands cannot be fully taken into account under the uniform standards. On the other hand, it should be clear that self-maintenance renewal has its own disadvantages: the lack of professional technical support, and the weak motivation of local residents who are not the owners of their dwellings. State-owned housing is naturally more vulnerable to government policies, and in China's case, it also reduces incentive to undertake courtyard renewal. In fact, where land and often also buildings are owned by the state or by collective organizations, government decisions prevail over private initiative. In the $80 \mathrm{~s}$ and $90 \mathrm{~s}$, in government-led reconstruction or demolition projects, public housing residents, who were forced to accept the government's decisions, had no right to express their own ideas and requirements relating to rehabilitation projects. Without a review of the property rights policy, it remains unrealistic to expect householders to invest in ordinary maintenance interventions.

\section{Discussion and Conclusion}

Having examined the main transformations and impacts produced by the rehabilitation project at the spatial and social level, we can focus on three main issues still requiring more appropriate solutions. These impacts can be examined through three aspects and their consequent socio-economic effects.

\subsection{Issues of Design and Maintenance}

Several design problems and subsequent maintenance issues have emerged after several years of monitoring:

- Natural light in the west and east wings of No. 41 Courtyard, and kitchen and washroom space, do not adequately meet the requirements of today's living standards;

- The new type of courtyard is higher than the traditional courtyard, resulting in a depressing psychological influence from current spatial scales;

- The grey and white south China style wall painting has been criticised as not attuned to Beijing Old City's architectural style;

- The issue of disrepair is evident in today's Ju Er Hutong, including peeling paint and waste material and garbage polluting the communal space of the yard. Efficient administration needs to be carried out. 


\subsection{Beneficiaries of the Project}

It is a challenge to find any prime beneficiaries/inhabitants who live in the new-type courtyard buildings, and the reason is clear. The inhabitants, discovering that the value of their homes had increased enormously, could hardly have been expected to pass up the opportunity. Therefore, it seems to be quite rational and voluntary for them to decide to settle down elsewhere and to rent or sell their own dwelling at a significant price.

It should be stressed that the high value of the rehabilitated courtyard buildings can be attributed not only to housing marketization and tourism development but also to their desirable living conditions and housing quality, particularly compared with other poor-condition courtyards in the area. In Beijing, the return of the middle classes to the inner city is actually a voluntary action which constitutes part of the reduction of population pressure in the old city; therefore, it does not seem intolerable. But it is contrary to the original intention of the architects who wanted to improve the living environment for local inhabitants. Besides this, the sense of loss for a home constitutes part of the psychological cost of displacement, although it was rarely considered in the rapid process of urban renewal in Beijing. Indeed, under the result-oriented conception, the impacts of gentrification are easily ignored in any scientific approach.

\subsection{The Issue of Local Commercial Activities}

Furthermore, the development of tourism accelerated the homogenization of diverse forms of industry. Local industry generally existed to satisfy daily needs until 2005. With the increase in tourism and the inflated rents, businesses serving the local community are increasingly being pushed out of the area. Meanwhile, the proportion of restaurant and beverage stores is sustaining rapid growth because of their high revenue [20]. Today, thirteen restaurants and cafés and two creative clothes shops attract a huge amount of tourists and only one convenience store and one laundry serve local residents in Ju Er Hutong. This demonstrates how tourism has influenced and changed both commercial activities and residents' daily lives.

\subsection{Conclusion}

The rehabilitation of $\mathrm{Ju}$ Er Hutong emphasizes the possibility that some of the Old City lifestyle might be preserved through an "organic renewal" method. In view of its outcome, could we consider it an ideal solution for urban preservation in the long term? If we compare it with the large-scale demolition and reconstruction which numerous Chinese old districts have experienced, the answer is yes. But if we consider the long-term in relation to the social and economic context, the consequences might be more harmful than positive.

How to negotiate the conflict between preservation and marketization is still a critical question when formulating policies for the rehabilitation of Chinese historical urban areas. However, in light of its spatial and functional outcomes, the project here presented allows us to recognize some non-secondary aspects concerning its effectiveness. In other words, it gives us lessons and warnings which can be summarized as follows:

(1) With respect to methods of actualizing tradition: the project shows that this type of courtyard house has a high potential for replication in a contemporary context. However, in their current use, the new built courtyards are not used as "community space", and this is only partially a result of the project in itself, stemming rather from a disconnection between the courtyard's living potential and the lifestyles of the new inhabitants.

(2) With respect to innovations in the functions of the central lane: the project demonstrates that it is possible to reintroduce the lanes in more evolved forms, which adapt to new social demands. However, this evolution is likely to leave no room for even a partial conservation of street life, which is today homologated 
around commercial activities.

(3) With respect to the maintaining the character of urban forms: while introducing a new type of courtyard house, the project manages to keep some formal cornerstones of the original morphological structure. However, the structure of the new courtyard houses is not fully integrated into the surrounding urban fabric. Besides the two historical courtyard houses preserved, which are rather dilapidated today, $70 \%$ of houses were torn down during the rehabilitation project, losing many traces of the original urban form.

(4) With respect to methods of preserving the "telling images" of the historic city: the project conserves one of the few historic elements still present in the area. However, the large-scale replacement of the existing residential tissue led to the disappearance of those elements that could have maintained a dialogue between the past and present city.

(5) With respect to mobility: the spatial character of the Hutong was marked for having mostly parking areas in public spaces. Since there is no prohibition or restriction for vehicles, a mobility system offering a wide range of transportation for local residents and tourists is today active. However, such a system is deficient in terms of health and safety, and a policy to limit mobility is needed.

(6) With respect to social composition: the first two phases of the project managed to keep $25.9 \%{ }^{4}$ of the original residents due to the creation of a high number of small apartments. This means that 211 new families (about 610 residents) moved into Ju Er Hutong after the rehabilitation project. The precise number of original residents who remained after the completion of the entire rehabilitation project is still unknown. Even considering that a policy to reduce overcrowding implies the replacement of some original residents, their substitution appears to be excessive, and it would have been better to provide greater support to maintain a larger number of them.

\footnotetext{
${ }^{4}$ The calculation of the data is based on the statistic table provided $\mathrm{Wu} 1994,170$.
}

(7) With respect to public space: the project produced an increase in housing value which was profitable for diverse types of users, from the dwellers to the traders, but it did not produce a corresponding improvement in terms of public spaces and public services. The preserved old trees in the courtyards constitute an unsatisfactory amount of green space for $\mathrm{Ju}$ Er Hutong. These spaces are not sufficient to meet the demands of inhabitants, and in this respect it is hard to expect a revival of a community sentiment which was based on a sense of identity and unique spatial character.

In conclusion, we are not dealing with an optimal solution, but with a serious attempt to reformulate important issues related to the process of transformation of Chinese historical cities. This attempt shows how the limitations of the project above mentioned can be related only in part to the inadequacy of spatial and functional solutions provided by the architectural and planning project. On the contrary, they are due to a great extent to the urban planning regulations and operational conditions (at social, economic and political levels) within which the project was situated. For this reason, concrete progress on the quality and effectiveness of policies for the conservation of historic centers cannot emerge solely from the operational field of architects and urban planners. In fact, many relevant decisions affecting the physical and functional levels, which are expected to remain in the hands of architects and planners, are removed completely from their competence.

Therefore, real progress stripped of rhetoric and misunderstandings can be achieved only if it stems from a profound reconceptualization of the idea of the historical city and its conservation. This must be a reconceptualization able to overcome the current limited operating conditions, which remain bound to market-led preservation goals rather than social and cultural outcomes. 


\section{References}

[1] Liu, J., Zhou, B., and Chen, L. 2007. "Analysis on the Chinese Ancient Urban form in Lifang System: A Case Study on Chang'an in Tang Dynasty." Sichuan Building Science 33 (6): 171-4.

[2] Deng, Y. 2005. "Spatial Form Evolution of Beijing Hutong." Beijing City Planning \& Construction Review 4: 17-9.

[3] Wu, L. Y. 1994. Rehabilitating the Old City of Beijing, 北 京旧城与菊儿胡同 [A Project in the Ju'er Hutong Neighbourhood]. Beijing: China Architecture and Building Press.

[4] Li, X., Zhao, D. G., and Zhou, Y. F. 2012. 八旗通志 [The Story of Eight Banners]. Changchun: Jilin Literature and History Publishing House.

[5] Li, T. S., and Zhang, A. D. 2010. 南锣鼓巷史话 [The Story of Nan Luo Gu Xiang]. Beijing: Beijing Publishing House.

[6] Liang, S. Y. 2014. Remaking China's Great Cities: Space and Culture in Urban Housing, Renewal, and Expansion. Abingdon: Routledge.

[7] Ian, D. J. 2004. Wild Grass: Three Stories of Change in Modern China. New York: Pantheon Books.

[8] Wu, L. Y. 2000. Rehabilitating the Old City of Beijing: A Project in the Ju'er Hutong Neighbourhood (Urbanization in Asia). Vancouver: University of British Columbia Press.

[9] Zhang, D. 2015. Courtyard Houses of Beijing: Lessons from the Renewal. Traditional Dwellings \& Settlements Review (TDSR) 27 (1): 69-82.

[10] Sun, J. 2008. “Ju Er Hutong Residenrial Mode.” Master. dissertation, Hu Nan University.

[11] Lees, L. 2003. "Visions of 'Urban Renaissance', the Urban Task Force Report and the Urban White Paper." In Urban Renaissance? New Labour, Community and Urban Policy, edited by R. Imrie and M. Raco. Bristol: Policy
Press, 61-82.

[12] Zhou, J. 2012. "Urban Vitality in Dutch and Chinese New Towns: A Comparative Study between Almere and Tongzhou." Ph.D. dissertation, Delft University of Technology, Delft.

[13] Samira, R., Zul, A. B. A. A., and Syed, Z. A. I. 2009. "Public Space and its Implication for Conservation of the Historic Living City of Melaka." Paper presented at APSA Congress, Ahmedabad, Gujarat, India.

[14] Song, Z. N., Chen, W., Zhang, G. X. and Zhang, L. 2010. "Spatial Accessibility to Public Service Facilities and Its Measurement Approaches." Progress in Geography 29 (10): 1217-24. doi: 10.11820/dlkxjz.2010.10.009.

[15] Liu, B. Y., Ning, X., Gong, J., and Ning, Y. 2014. 美丽中 国宽窄梦 [Beautiful China, the Dream of KuanZhai Alley]. Beijing: China Architecture and Building Press.

[16] Wang, X. K. 2009. "The Psychological Analysis on Beijing Siheyuan.” Master dissertation, Beijing Forestry University.

[17] Zhang, D. 2016. Courtyard Housing and Cultural Sustainability: Theory, Practice, and Product. Abingdon: Routledge.

[18] Cinà, G. 2014. "Idee e Pratiche della Conservazione in Cina nell'epoca del Socialismo di Mercato (Idea and Practices of the Conservation in China in the Era of Market Socialism)." Archivio di Studi Urbani e Regionali 111: 5-31. doi: 10.3280/ASUR2014-111001.

[19] Yu, S. S. 2017. "Courtyard in Conflict: The Transformation of Beijing's Siheyuan during Revolution and Gentrification." The Journal of Architecture 22 (8): 1337-65. doi: 10.1080/13602365.2017.1394349.

[20] Liu, M., and Liu, A. L. 2015. "Urban Architectural Heritage Reuse from the Perspective of Industrial Types: A Case Study of Nanluoguxiang Street in Beijing City." Tourism Tribune 30 (4): 115-26. doi: 10.3969/j.issn.1002-5006.2015.04.011. 